\title{
The Relevance of absorptive capacity in firms' innovation strategies measured via bibliometric analysis
}

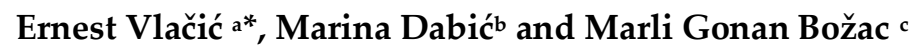 \\ ${ }^{\text {a }}$ Faculty of Economics and Business, University of Rijeka \\ b University of Zagreb, Faculty of Economics and Business \\ c Juraj Dobrila University of Pula, Croatia
}

\begin{tabular}{|c|c|}
\hline ABSTRACT & ARTICLE INFO \\
\hline $\begin{array}{l}\text { Absorptive capacity (ACAP) as a function of systematic knowledge } \\
\text { management is widely recognized as the catalyst for successful innovation } \\
\text { performance in firms, particularly when it comes to identifying business } \\
\text { opportunity information from the outside world and assimilating it into a } \\
\text { firm's innovation process. The concept of absorptive capacity became a } \\
\text { widely researched topic in the area of organization and management, } \\
\text { consequently, the definition of the ACAP components, its } \\
\text { operationalization and outcomes, is extremely heterogeneous and has } \\
\text { greatly affected the research production on ACAP. Therefore, the question } \\
\text { arising is: Which approach to absorptive capacity will enable its being } \\
\text { truly recognized as a concept at a global level, and in which areas of } \\
\text { economy and business is ACAP most frequently encountered, particularly } \\
\text { when it is connected to innovation processes? Based on a sample of } 1288 \\
\text { papers within Web of Science Core Collection, this paper presents a } \\
\text { bibliometric analysis of relevant publications on ACAP with the specific } \\
\text { aim of gaining a deeper insight into the relevance of the impact of } \\
\text { absorptive capacity on a firm's innovation strategy. The results were } \\
\text { systematized in a form of quantitative bibliographic review. The purpose } \\
\text { of the analysis was to determine the existing level of the empirical and } \\
\text { theoretical efforts in the research on ACAP, with a particular focus on } \\
\text { firms and their innovation processes as well as knowledge management } \\
\text { processes. }\end{array}$ & $\begin{array}{l}\text { Keywords: } \\
\text { absorptive capacity, } \\
\text { innovation process, } \\
\text { bibliometric meta-analysis, } \\
\text { strategic management } \\
\text { *Corresponding author: } \\
\text { ernest.vlacic@gmail.com } \\
\text { Article history: } \\
\text { Received } 10012017 \\
\text { Revised } 14022017 \\
\text { Accepted } 22032017 \\
\text { This article was presented at } \\
\text { the 5th International OFEL } \\
\text { Conference on Governance, } \\
\text { Management and } \\
\text { Entrepreneurship. The } \\
\text { Paradoxes of Leadership } \\
\text { and Governance in the } \\
\text { Postmodern Society. (April } \\
\text { 7th - 8th, 2017, Dubrovnik, } \\
\text { Croatia, Governance } \\
\text { Research and Development } \\
\text { Centre CIRU), Zagreb, pp. } \\
\text { 438-450 }\end{array}$ \\
\hline
\end{tabular}

\section{INTRODUCTION}

In their quest to find the appropriate term to describe organizational capacity to recognize the value of new external information (knowledge), its assimilation and commercial implementation, Cohen and Levinthal $(1989,1990)$ suggested the term absorptive capacity (ACAP). The definition of ACAP was formulated as the ability of a firm to identify the value of new, external information, assimilate it, and apply it to commercial ends, where authors largely perceived it as a function of prior related knowledge. 
In the evolution of the discipline, a significant contribution was given by Zahra and George (2002), who recognized absorptive capacity as a key dynamic capacity that strongly influences the nature and sustainability of competitive advantage. The concept of ACAP has been used to explain various organizational phenomena (Zahra and George, 2002) in strategy (Nahapiet and Ghoshal, 1998) and technology management (Schilling, 1998; Rush, Bessant and Hobday, 2007; Rodriguez, Wise and Martinez 2013).

This paper is primarily focused on the in-depth analysis and review of the ACAP related research bibliography and registered publishing databases, with a particular emphasis on the relationship of ACAP and innovation strategies. Therefore, the principal objective of this paper is to determine the relevance of ACAP and provide a literature overview in the field of ACAP via a comprehensive bibliometric analysis. Notably, the specific objective is to assess the relevance of the ACAP research in firms, with a particular focus on innovation and innovation related strategies.

As the instrument to achieve our defined research objectives we have selected a commonly used methodological systematic review of the available bibliography in a form of a simplified meta-analysis (Dabić et al. 2014, 2015). Methodologically, the first step was to perform a thorough exploratory secondary analysis on the research literature related to the existing knowledge of the selected ACAP field. We only retained articles from journals indexed in the Web of Science database, as it can be considered most rigour and qualified. Articles in the database were retrieved using the search function and the lexemes (TS=(absorptive capacity) AND TS=(innovation) AND TS=(company OR firm OR SME) AND TS=(performance)) AND DOCUMENT TYPES: (Article).The search is conducted on February 20th, 2016 resulted 1288 articles which have been cited 25958 times.

The relevance of the topic can be corroborated by several earlier studies where meta-analysis or systematic reviews have been used (Maldonado, Vera and Keller 2015, Lewandowska, 2015).

\section{ROLE OF ACAP IN INNOVATION STRATEGIES}

In the context of innovation, a firm's absorptive capacity refers to its ability to assimilate and manage acquired knowledge, aiming at improving innovation outputs and achieving a competitive advantage (Abreu et al., 2008). In the world of globalization and fierce competition, where competitive advantage increasingly relies on knowledge, firms are trying to learn and develop skills faster than their rivals (Teece and Pisano, 1994). These skills need to be more dynamic in order to achieve an advantage over one's competitors. Dynamic capabilities enable firms to adjust to changing conditions that govern the market (Teece, Pisano and Shuen, 1997).

According to Dosi, innovation, which is closely and inextricably linked to the concept of knowledge, is a complex process at the level of knowledge research and its exploitation (Dosi, 1988). Innovation, as a direct result of knowledge or combinations of knowledge, is considered a fundamental component 
of entrepreneurship and a key element of business success (Dabic et al., 2009). Innovation and innovation potential are widely considered and recognized as some of the most important factors of firms' competitiveness. Today, innovation is a major factor in improving firms' productivity and efficiency, as well as product quality, and reducing production costs and production time.

According to Radosevic (2004), competitiveness and innovation activities are linked to national innovation capacity, which includes the implementation of $R \& D$ activities, dissemination of knowledge, market demand and, ultimately, absorptive capacity. Radosevic (2004) states that there is a general consensus among economists that innovation in enterprises play a key role in the process of sustainable long-term economic growth.

Research links between ACAP and innovation processes in firms are the main subject of this paper, and there is a large amount of scientific literature exploring their correlation. Some of the authors discussing the topic are Lin 2016, Liao 2009, Forés and Camison 2016 Grandinetti 2016, Bahli et al 2013.

However, ACAP should not be explored only as an important function in firms' implementation of innovation and related performances, but also in the context of its competitive advantage. From the resource-based view (RBV), a firm's existing knowledge or its ability to acquire new knowledge is the highest ranking strategic resource that a firm can own. Many authors (Barney 1986, Grant 1996, Argote and Ingram 2000) use a resource-based approach as a basis for a sustainable competitive advantage, which essentially presupposes the existence and proper management of resources and capacities within the firm. These resources then participate in achieving a sustainable competitive advantage (SCA).

Absorptive capacity is a basic function of the fundamental processes of learning in firms and can be a source of competitive advantage. Thus developed, ACAP enables the identification, adaptation and embodiment of external knowledge within firms' own routines (Cohen and Levinthal, 1990; Lane, Koka and Pathak, 2006). Knowledge-based competitive advantage is innovative per se in the way it develops in the process of creating new products, services, processes or structures. Firms based on knowledge can not only respond quickly to customer needs, but also actively shape their expectations and goals for future products and/or services (Gurteen, 1998).

Firms achieve their competitive advantage not only by using their own key resources, but also by using their own internal ability to reconfigure their knowledge base and adapt to the conditions of market fluctuations (Kleinschmidt, De Brentani and Salome, 2007). Therefore, the ability to produce, share and use knowledge, which represents essentially the core of a firms' ACAP, can be considered crucial for gaining and maintaining a competitive advantage (Barney, 1986; Cohen, Levinthal, 1990).

In his work Chauvet (2002) claims that the transfer of knowledge is one of the key prerequisites to achieve a sustainable competitive advantage, thus reaffirming the direct link of the SCA based on 
knowledge and absorptive capacity. In this way, knowledge is a natural moderator connecting absorptive capacity and sustainable competitive advantage. Chauvet goes on to say that, in fact, ACAP and knowledge transfer are forming a closed circuit, and puts knowledge in the first place, its analysis in the second and the transfer of knowledge in the third place, all in order to achieve and maintain a sustainable competitive advantage.

When it comes to the size of firms, research in the field of strategic management suggests that one of the most important distinctions in the functioning of large companies vs. SMEs is their ability to overcome barriers and constraints that come from their capacity or size. Thus, the prevailing opinion is that small and medium enterprises are very limited in terms of business relationship development, particularly in terms of the outside world and therefore possess limited ability to acquire new knowledge from the outside world. (Grandinetti, 2016). Grandinetti further says that the above statement becomes clearer when one considers that the resource theory views sustainable competitive advantage as a priority for learning resource/capacity. Das and Teng (2000) argue that external resources available to a firm (external knowledge, materials or other resources) are not in its immediate direct ownership, but are still within reach through developed partnerships and networks with other organizations that the firm can develop in the environment.

Grandinetti (2016) also states that some authors even suggest that the "interorganizational relationship should be seen as a specific modality of organic growth of businesses" (which especially applies to SMEs), while at the same time it can be seen as a lever supporting their individual growth (McKelvie and Wiklund, 2010 Furlan, Grandinetti and Paggiaro, 2014).

\section{Research on ACAP in Croatia}

When it comes to scientific research on absorptive capacity in Croatia, according to available information, it has not been the focus of the Croatian scientific community so far. We may assume that the reason lies in the fact that producing thorough and relevant ACAP related studies requires a multidisciplinary scientific approach that would encompass and cover its complex scope. Therefore, in the relevant available and published literature in Croatia there is a noticeable lack of conceptual and empirical scientific knowledge about absorptive capacity of firms; in particular, there are no documented procedures of the operationalization of ACAP at any level.

Some documents, such as 'Strategy for Fostering Innovation' (MINGO, 2014), state that the limited and low level absorptive capacity of domestic firms, especially in the segment of small and mediumsized companies, limits the acquisition and application of available domestic or foreign knowledge and its transfer into technology development. In addition, the overall ability and capacities of firms' research and development in the private sector has been influenced by some historical factors. In particular, by the restructuring and privatization of state-owned enterprises in the 1990s, which 
resulted in the closing down of a large number of R\&D departments, which had once been wellintegrated in the production of state-owned enterprises. Today, the national institutional framework is becoming increasingly aware of the role of ACAP in firms, thus in the recently published 'Strategy for Smart Specialization in Croatia for Period 2016 - 2020' (MINGO, 2016) ACAP is considered one of the most important aspects of Smart specialization strategy.

\section{META-ANALYSIS OF ACAP BIBLIOGRAPHY}

Since ACAP is a hybrid between social/humanistic and technology learning sciences, we have decided to search through Web of Science (WoS) Core Collection as the primary source of information. In order to determine the relevance of ACAP, as suggested in Dabic, González-Loureiro and Furrer (2015), the first step was to systematize filtered bibliographic records contained in WoS. Our search included works that had been published until the end of 2016, and the key words used were absorptive capacity, innovation, firm or company, performance. As a result, 1288 papers were identified to contain composites of researched keywords.

Firstly, we observed the chronological profile of ACAP-related published papers, where the growth curve of published papers has been exponentially increasing since the first records in the early 1990s (Figure 1). A noticeable increase in publishing can be observed from the mid 2000s onwards, where the discipline has been strongly advancing in its visibility and scientific relevance.

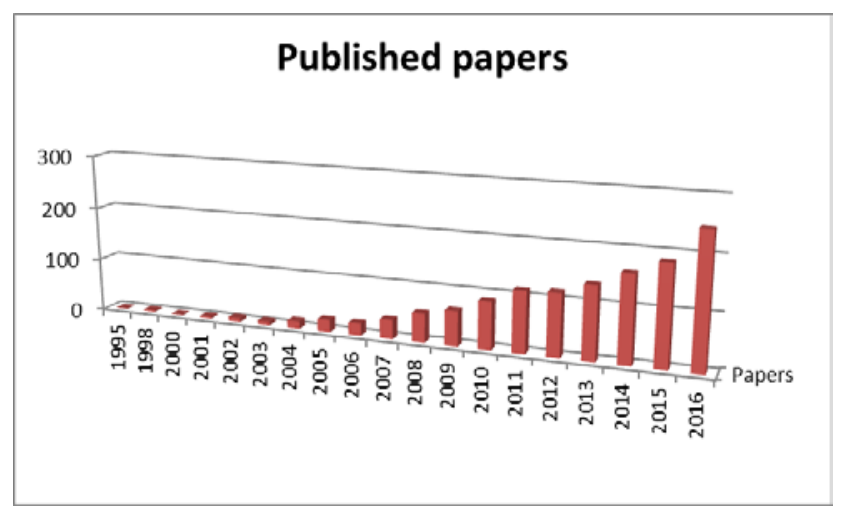

Figure 1. Chronological records of ACAP publishing,

Source: WoS

When it comes to the analysis of published articles in relevant publications, a relative balance may be noticed. Nevertheless, Research Policy, Strategic Management Journal, Journal of Business Research and Technovation are preferentially selected in the observed field of ACAP. Table 1 shows the top twenty ACAP publishing journals that cumulatively cover more than $45 \%$ of total publishing. 
Table 1. Top 20 ACAP publishing journals

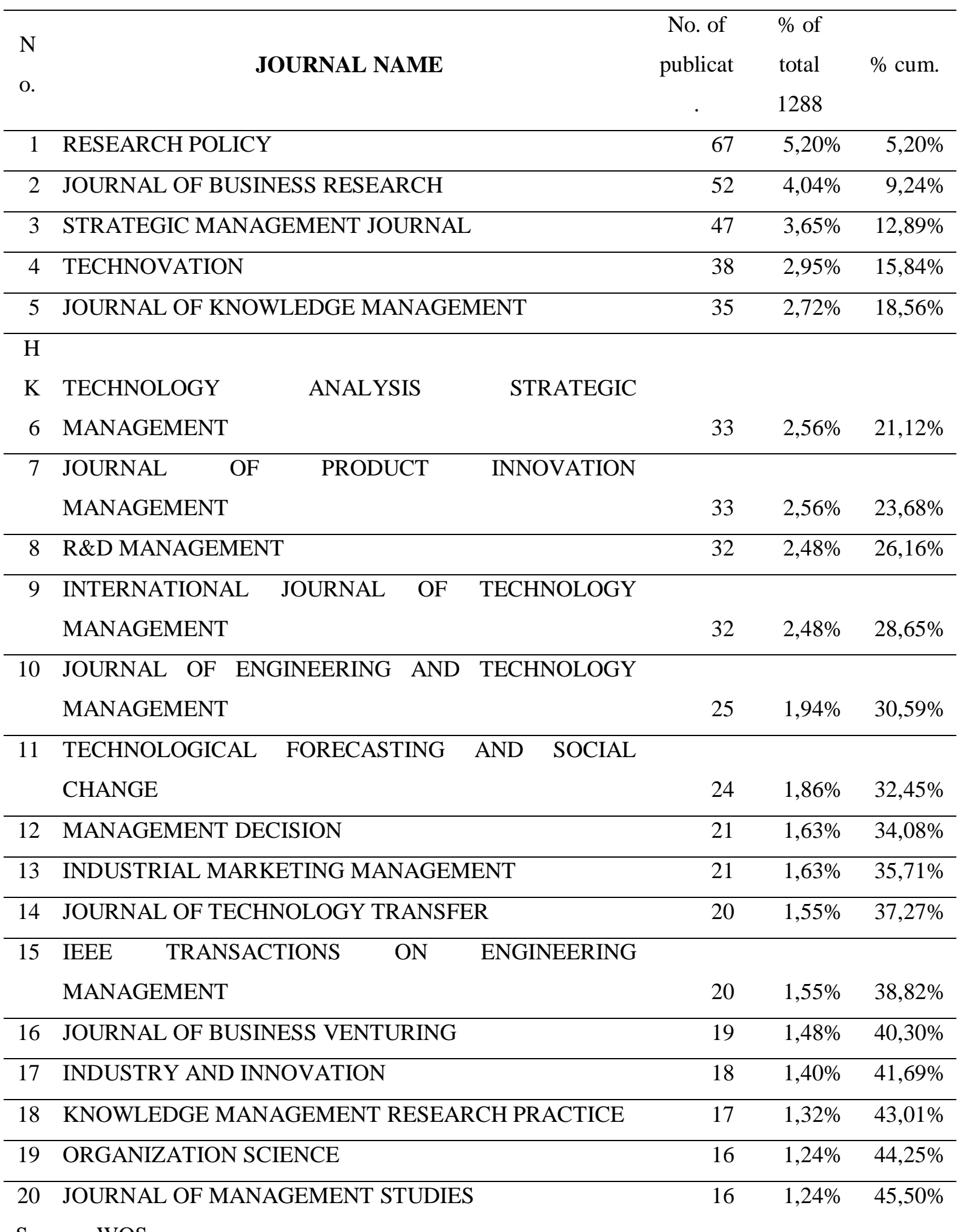

Source : WOS

The applicability of ACAP in specific areas covers a wide range. Our research has identified 30 areas that are covered by at least one publication. These papers are often classified through a multicategory selecting principle, which means that ACAP is presented as a multidisciplinary field. A large number

PAGE 6| Journal of Corporate Governance, Insurance, and Risk Management | 2020, VOL. 7, Series. 1 
of published papers is related to technological innovation in engineering, public administration and operation in research and development. However, most of them are published in the area of business and economics, which means that the majority of researchers and research interest derive from the business sector. Table 2 shows the first fifteen areas of research in the classification are shown in Table 2.

Table 2. Most ACAP related researched areas

\begin{tabular}{|c|c|c|c|}
\hline & Research area & $\begin{array}{l}\text { No. of } \\
\text { papers }\end{array}$ & $\%$ of 1288 \\
\hline 1. & BUSINESS ECONOMICS & 1167 & $90,61 \%$ \\
\hline 2. & ENGINEERING & 218 & $16,93 \%$ \\
\hline 3. & PUBLIC ADMINISTRATION & 121 & $9,39 \%$ \\
\hline 4. & OPERATIONS RESEARCH MANAGEMENT SCIENCE & 98 & $7,61 \%$ \\
\hline 5. & INFORMATION SCIENCE LIBRARY SCIENCE & 86 & $6,68 \%$ \\
\hline 6. & SCIENCE TECHNOLOGY OTHER TOPICS & 51 & $3,96 \%$ \\
\hline 7. & ENVIRONMENTAL SCIENCES ECOLOGY & 43 & $3,34 \%$ \\
\hline 8. & COMPUTER SCIENCE & 42 & $3,26 \%$ \\
\hline 9. & GEOGRAPHY & 28 & $2,17 \%$ \\
\hline \multicolumn{4}{|l|}{10} \\
\hline & PSYCHOLOGY & 15 & $1,16 \%$ \\
\hline \multicolumn{4}{|l|}{11} \\
\hline$\cdot$ & SOCIAL SCIENCES OTHER TOPICS & 14 & $1,09 \%$ \\
\hline \multicolumn{4}{|l|}{12} \\
\hline . & URBAN STUDIES & 8 & $0,62 \%$ \\
\hline \multicolumn{4}{|l|}{13} \\
\hline & AGRICULTURE & 6 & $0,47 \%$ \\
\hline \multicolumn{4}{|c|}{14} \\
\hline & INTERNATIONAL RELATIONS & 5 & $0,39 \%$ \\
\hline 15 & FOOD SCIENCE TECHNOLOGY & 4 & $0,31 \%$ \\
\hline
\end{tabular}

Source: WoS

When it comes to geographical distribution, the most productive authors of the ACAP related publications in the defined research scope derive from the USA, Spain, England and P.R. China (Figure 2). More precisely, the analysis shows that out of 1288 processed papers, 313 are published by 
authors from the United States, 199 are the work of Spanish authors, 166 by the UK based researchers, while 139 of them derive from P.R. China. Within the first 20 countries related ACAP publishing, except for the works from the United States, all the rest come from Europe or Asia.

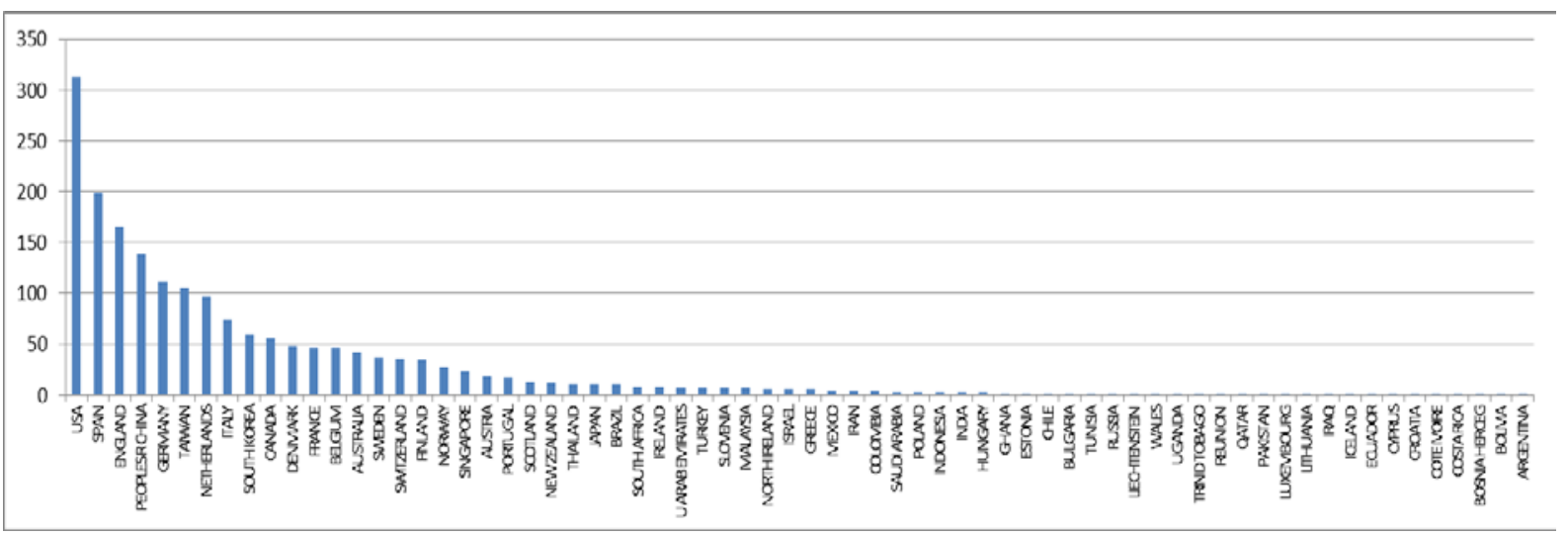

Figure 2. Geographical/country related ACAP publishing

Source: WoS

Statistically processed results covering Croatia's regional neighborhood show 6 papers from Slovenia, 68 from Italy, 18 from Austria and 2 of them from Hungary. Only one paper belonging to the Croatian scientific milieu has been recorded in WoS, which in its scope does not directly research absorptive capacity of firms, but is more focused on other aspects of innovation. The extension of this research, outside of WoS boundaries (using Google Scholar) has revealed that there are some other sporadic attempts to deal with ACAP in Croatian publications, but these are of a more descriptive and informative nature. From the national policy perspective, ACAP in companies is mentioned at a limited and only conceptual context in few other documents (national strategies) published by the Croatian Government.

The most productive authors are Lichtenthaler U. with 22 publications, Molina-Morales F.X. with 15 and Roper S. with 12 papers. The complete list of top fifteen authors in ACAP related publications is presented in Table 3.

Table 3. ACAP topics leading authors,

\begin{tabular}{lr}
\hline Author & No. of citations \\
\hline LICHTENTHALER U & 22 \\
\hline MOLINA-MORALES FX & 15 \\
\hline ROPER S & 12 \\
\hline WANG YD & 11 \\
\hline ZAHRA SA & 10 \\
\hline
\end{tabular}

PAGE 8| Journal of Corporate Governance, Insurance, and Risk Management | 2020, VOL. 7, Series. 1 


\begin{tabular}{lr}
\hline VANHAVERBEKE W & 10 \\
\hline NAVAS-LOPEZ JE & 9 \\
\hline DUYSTERS G & 9 \\
\hline VOLBERDA HW & 8 \\
\hline PETRUZZELLI AM & 8 \\
\hline BRETTEL M & 8 \\
\hline VAN DEN BOSCH FAJ & 7 \\
\hline TSAI KH & 7 \\
\hline LI Y & 7 \\
\hline HURMELINNA-LAUKKANEN P & 7
\end{tabular}

Source: WoS

Finally, by conducting a meta-analysis based on 1288 filtered works, we have identified a total of 22366 citations registered in WoS. A list of fifteen most cited papers is shown in Table 4. The table shows that Lane and Lubatkin's paper 'Relative Absorptive Capacity and Interorganizational Learning' from 1998 has been cited more than 1400 times. The second place is held by W.P. Tsai with the paper entitled 'Knowledge transfer and intraorganizational networks: Effects of network position and absorptive capacity on innovation and business unit performance' published in 2001 with over 1050 citations. Tsai is followed by Ahuja and Katila's 'Technological acquisitions and the innovation performance of acquiring firms: A longitudinal study' presented in 2001 with a total of 562 citations. The first fifteen papers indicated in the table cumulatively exceed the $25 \%$ of all citations in the research scope, which somehow sheds a particular light on the importance of these 15 presented works that influenced past ACAP research.

Table 4. ACAP leading citing papers/authors,

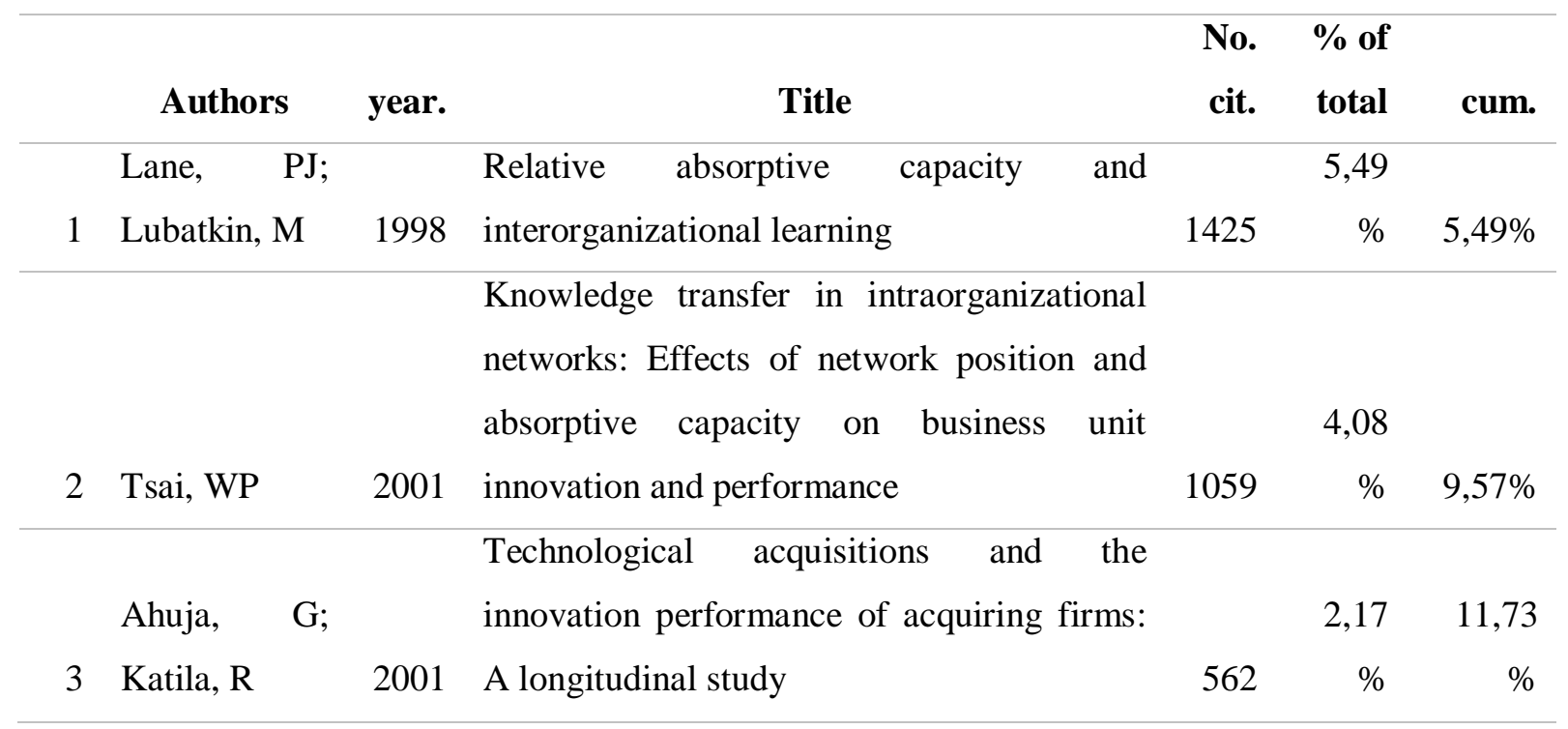




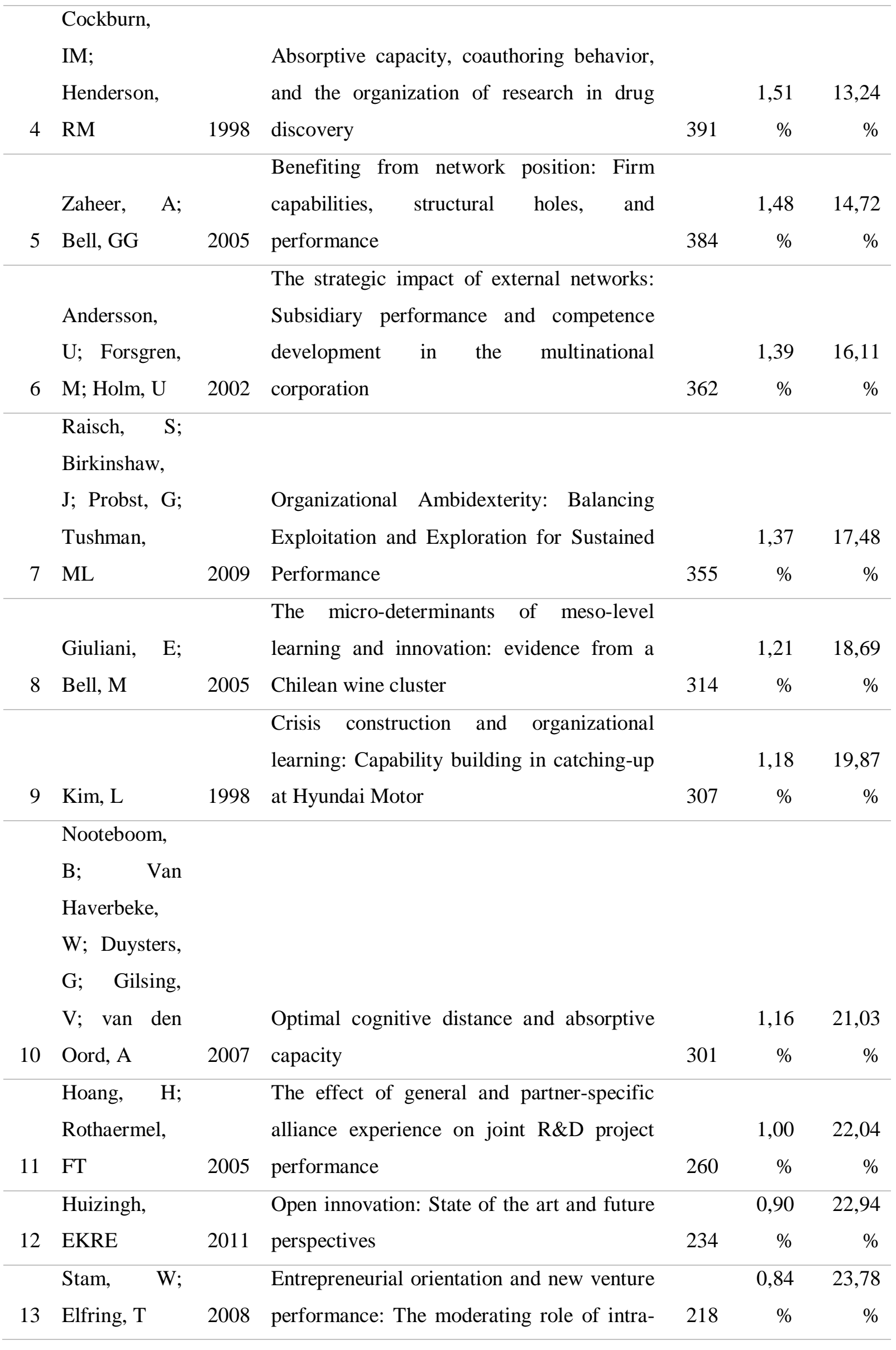


and extraindustry social capital

\begin{tabular}{|c|c|c|c|c|c|c|}
\hline & $\begin{array}{l}\text { Caloghirou, } \\
\text { Y; Kastelli, I; } \\
\text { Tsakanikas, }\end{array}$ & & $\begin{array}{l}\text { Internal capabilities and external knowledge } \\
\text { sources: complements or substitutes for }\end{array}$ & & 0,84 & 24,62 \\
\hline \multirow[t]{5}{*}{14} & A & 2004 & innovative performance? & 218 & $\%$ & $\%$ \\
\hline & & & Absorptive $\quad$ Capacity, $\quad$ Environmental & & & \\
\hline & & & Turbulence, And The Complementarity Of & & & \\
\hline & & & Organizational Learning Processes & & & \\
\hline & Lichtenthaler, & & (Retracted article. See vol. 56, pg. 1830, & & 0,84 & 25,45 \\
\hline 15 & $\mathrm{U}$ & 2009 & 2013) & 217 & $\%$ & $\%$ \\
\hline
\end{tabular}

\section{CONCLUSIONS}

The results of the meta-analysis showed a noticeable multidisciplinary and interdisciplinary character of the selected topic - absorptive capacity of firms. The analysis showed that the area of ACAP is increasingly attractive, very actual and scientifically relevant, particularly in areas where innovation and high added value products/services are identified as key factors in achieving and maintaining a long-term sustainable competitive advantage. As confirmed by the overview of researched areas, ACAP often explores interactions related to innovation in firms, usually particularly focusing on technological innovation and $\mathrm{R} \& \mathrm{D}$, regardless of being realized internally or externally, or both.

Due to its multidisciplinary and interdisciplinary character, which requires a thorough understanding of a large number of operating variables in firms, ACAP is often too complex to be operationalized. This complexity leads to a variety of contextual approaches in its measurement and operationalization and so far none of the existing models or methodological approaches have shown themselves to be ideal or highly prescriptive for determining a firm's ACAP.

The importance of ACAP is primarily recognized in developed countries (USA, Spain, UK, Denmark), but also in the leading emerging world economy, P.R. China. It may be concluded that countries and economies with somewhat stronger industrial backgrounds, past or future, are more inclined to explore and understand the ACAP interactions and influence aiming at firms' competitiveness.

Unfortunately, ACAP has been rather neglected and unembraced in the authors' own country, Croatia, where almost none or very little research activity has been recorded in relation to the ACAP field. This is particularly visible in terms of ACAP related publishing, which is almost nonexistent.

Among other objectives, this paper aims at raising awareness of the importance of ACAP and possibly encouraging interest in ACAP publishing within the Croatian research milieu. This would be a step forward in assisting national firms and the institutional framework in understanding and creating a 
better environment for boosting innovation, which will consequently stimulate the increase of the firms' international competitiveness.

Finally, the presented trends show a continuous increase in the publishing volume, which leads us to conclude that ACAP will continue to be a very attractive and interesting area for further research not only for researchers in Croatia, but at the global level as well.

Funding: This research received no external funding

\section{REFERENCES}

Abreu, M. G., Kitson, M., Grinevich V., Savona, M., 2008. Absorptive Capacity and Regional Patterns of Innovation. DIUS Research Report 08 11. Centre for Business Research (CBR), University of Cambridge: University of Cambridge, UK.

Argote, L. and Ingram, P. 2000, Knowledge transfer : a basis for competitive advantage in firms, Organizational Behavior and Human Decision Processes, Vol. 82, №. 1, pp. 150-169.

Bahli, B., 2012. Enabling innovation in information technology outsourcing: An empirical study. In ACIS 2012: Location, location, location: Proceedings of the 23rd Australasian Conference on Information Systems 2012 (pp. 1-8). ACIS.

Bahli, B., Wettenberg, C., Borgman, H.P., Heier, H., 2013. The role of absorptive capacity in information technology outsourcing and innovation performance: a moderated mediation analysis. In System Sciences (HICSS), 2013 46th Hawaii International Conference on (pp. 4635-4644). IEEE.

Barney, J. B. 1986. Organizational culture: can it be a source of sustained competitive advantage? Academy of Management Review, Vol. 11, N. 3, pp. 656-665.

Chauvet, V., 2002. Absorptive Capacity And Knowledge Transfer Propensity : Towards The Obtaining Of A Competitive Advantage. Organizational Learning, Knowledge \& Capabilities Conference.

Cohen, W. M., Levinthal, D.A.,1989. Innovation and learning: the two faces of R\&D'. The Economic Journal, 99, 569-96.

Cohen, W. M., Levinthal, D.A.,1990. Absorptive capacity: A new perspective on learning and innovation, Administrative Science Quarterly, Vol. 35, No. 1, pp. 128-152, 1990.

Das T. K., Teng B., 2000. A resource-based theory of strategic alliances. Journal of Management 26(1), 31-61.

Dosi, G., 1988. Sources, procedures, and microeconomic effects of innovation. Journal of Economic Literature, 26 (3):1120-1171.

Dabić, M., Kiessling, T., Andrijević, S., Matovac, V. 2009. An Exploratory Study of Innovation in Croatia after Independence. Naše gospodarstvo. 55 (2009), 1-2; 40-50. 
Dabic, M., González-Loureiro, M., \& Furrer, O. (2014). Research on the strategy of multinational enterprises: key approaches and new avenues. BRQ Business Research Quarterly, 17(2), 129-148.

Dabic, M., González-Loureiro, M., \& Harvey, M. (2015). Evolving research on expatriates: what is 'known'after four decades (1970-2012). International Journal of Human Resource Management, 26(3), 316-337.

Forés, B., Camisón, C., 2016. Does incremental and radical innovation performance depend on different types of knowledge accumulation capabilities and organizational size? Journal of Business Research 69(2): 831-848.

Furlan, A., Grandinetti, R., Paggiaro, A., 2014. Unveiling the growth process: entrepreneurial growth and the use of external resources. International Journal of Entrepreneurial Behaviour \& Research 20(1), 20-41.

Grandinetti, R., 2016. Absorptive capacity and knowledge management in small and medium enterprises. Knowledge Management Research \& Practice, 14, 159-168.

Grant, R. M., 1991. The resource-based theory of competitive advantage: implication for strategy formulation, California Management Review, spring, pp. 114- 135.

Gurteen D., 1998. Knowledge, Creativity and Innovation, Journal of Knowledge Management, Vol. 2 Iss: 1 , pp. $5-13$

Kleinschmidt, E. J., De Brentani, U., Salomo, S., 2007. Performance of global new product development programs: a resource-based view, Journal of Product Innovation Management, Vol. 24(5), pp. 419-441.

Lane, P., Koka, B., Pathak, S., 2006. The reification of absorptive capacity: A critical review and rejuvenation of the construct, Academy of Management Review, No. 31, Vol. 4, pp. 833-863.

Lewandowska, M. S., 2015. Capturing Absorptive Capacity: Concepts, Determinants, Measurement Modes and Role in Open Innovation. International Journal of Management and Economics, 45.

Liao, S.H., Wu, C.C., Hu, D.C. and Tsuei, G.A., 2009. Knowledge acquisition, absorptive capacity, and innovation capability: an empirical study of Taiwan's knowledge-intensive industries. Technology, 11, p.13.

Lin, H.F., Su, J.Q., Higgins, A., 2016. How dynamic capabilities affect adoption of management innovations. Journal of Business Research, 69(2), pp.862-876.

Maldonado, T., Keller, R., Vera, D., 2015. Opportunities in the absorptive capacity construct: a metaanalysis to improve theoretical foundations and measures. ACAD MANAGE PROC January 2015 (Meeting Abstract Supplement) 15545.

Mckelvie, A., Wiklund, J., 2010. Advancing firm growth research: a focus on growth mode instead of growth rate. Entrepreneurship Theory and Practice 34(2), 261-288.

MINGO, 2014. Strategija Poticanja Inovacija Republike Hrvatske 2014. - 2020. Narodne Novine Republike Hrvatske, 153, 74.

MINGO, 2016. Strategija pametne specijalizacije Republike Hrvatske za razdoblje 2016.-2020. Narodne Novine Republike Hrvatske, 2, 2. 
Nahapiet, J., Ghoshal, S., 1998. Social capital, intellectual capital, and the organizational advantage. Academy of Management Review 23(2), 242-266.

Radošević, S., 2004. A Two-Tier or Multi-Tier Europe? Assessing the Innovation Capacities of Central and East European Countries in the Enlarged EU. JCMS, 42,

Rakthin S., 2013. Contextual Differentiation Of Absorptive Capacity: Empirical And Conceptual Development, Michigan State University, USA; dissertation ttps://etd.lib.msu.edu/ /accessed $24^{\text {th }}$ may 2016.

Rodriguez, C. M.; Wise, J. A.; Martinez, C. R. (2013), "Strategic capabilities in exporting: An examination of the performance of Mexican firms”, Management Decision, 51 (8): 1643-1663.

Rush, H., Bessant, J., \& Hobday, M. (2007). Assessing the technological capabilities of firms: Developing a policy tool. R\&D Management. 37, 221-236.

Schilling, M. A., 1998.. Technological Lockout: An Integrative Model of the Economic and Strategic Factors Driving Technology Success and Failure. The Academy of Management Review, 23(2): 267284.

Teece, D. J., Pisano, G., Shuen, A., 1997. Dynamic Capabilities and Strategic Management. Strategic Management Journal, 18(7), 509-533. DOI: 10.1002/(SICI)1097- 0266(199708)18:73.0.CO;2-Z

Teece, D., Pisano, G., 1994. The Dynamic Capabilities of Firms: An Introduction (Working Paper). Laxenburg: International Institute for Applied Systems Analysis.

Zahra, S.A., George, G., 2002. Absorptive capacity: A review, reconceptualization, and extension, Academy of Management Review, 27, 2, 185-203. 